\title{
26-я Международная конференция Тихоокеанского конгресса морских наук и технологий (PACON-2019)
}

Тихоокеанский конгресс морских наук и технологий (Pacific Congress on Marine Science and Technology - PACON) - некоммерческая научная организация, объединяющая ученых, инженеров, специалистов промышленности и управления для обмена последними достижениями в области морских наук и технологий и эффективными подходами к их применению. Создана в 1983 г., в настоящее время является одной из старейших научных организаций в Тихоокеанском регионе. Первые два конгресса PACON были успешно организованы в 1984 и 1986 гг. в г. Гонолулу (США) и собрали каждый свыше 250 участников из более чем десяти стран. В дальнейшем конгрессы и конференции PACON проводились и в других странах Тихоокеанского региона, в частности в 1999 г. в России (Москва), где присутствовало около 400 человек. 25-я конференция состоялась в Китае (28-30 марта 2017 г., г. Жоушань). Конгрессы и конференции PACON служат площадками, на которых ученые и инженеры обмениваются результатами научных исследований, технических и коммерческих разработок в области морских наук и технологий.

26-я конференция, организованная совместно Президиумом ДВО РАН, Тихоокеанским океанологическим институтом им. В.И. Ильичёва (ТОИ) ДВО РАН и Дальневосточным федеральным университетом (ДВФУ), прошла во Владивостоке на базе Инженерной школы ДВФУ 16-19 июля 2019 г. Сопредседателями организационного комитета были председатель ДВО РАН академик В.И. Сергиенко, ректор ДВФУ к.ф.-м.н. Н.Ю. Анисимов и директор ТОИ ДВО РАН к.г.н. В.Б. Лобанов

Конференции РACON традиционно мультидисциплинарны. Общая тема 26-й конференции - «Морские науки и технологии для устойчивого развития». На конференции были представлены разнообразные сферы морских наук, от фундаментальных областей (физической, химической и биологической океанологии, климата, экологии, акустики океана, морской геологии) до прикладных: морской техники и технологий, включающих подводную робототехнику и связь, строительство и эксплуатацию морских и прибрежных сооружений, защиту от цунамиопасности, транспорт, морское рыболовство и аквакультуру, морскую возобновляемую энергетику. Значительное внимание было уделено социально-экономическим аспектам мореведения, таким как охрана прибрежных районов моря и побережий, образование в сфере морских наук, медицина и здравоохранение, прибрежный и морской туризм, морская политика. На заседаниях было рассмотрено 11 крупных тем, которые включали 27 секций.

В конференции приняли участие 262 специалиста из России (Владивосток, Москва, Санкт-Петербург, Мурманск, Севастополь, Томск, Петропавловск-Камчатский, всего 176 чел.) и из других стран: Китая (37 чел.), Японии (36 чел.), США (7 чел.), Вьетнама (4 чел.), Кореи (2 чел.), Индонезии (1 чел.), Филиппин (1 чел.) и Австралии (1 чел.). За четыре дня прошло 6 пленарных заседаний, на которые были приглашены ведущие отечественные и зарубежные специалисты, сделавшие 13 докладов, а также 45 секционных заседаний, на которых заслушали 178 устных, в том числе 10 приглашенных докладов. Работала секция стендовых докладов, где было представлено 43 доклада.

В 2017 г. ООН объявила Декаду исследования океана для устойчивого развития (2021-2030 гг.), чему был посвящен пленарный доклад С.М. Шаповалова (Институт океанологии им. П.П. Ширшова РАН, Москва) и В.Э. Рябинина (Межправительственная океанографическая комиссия ЮНЕСКО, Франция), открывший конференцию, а также круглый стол для прессы «Toward the UN Decade of Ocean Science for Sustainable Development: Current Challenges in the Pacific» («Навстречу объявленной ООН Декаде исследования океана для устойчивого развития»). Основная цель Декады - значительный прорыв в области морских исследований и разработки технологий освоения ресурсов океана, который потребует получения новых знаний, продвижения международного сотрудничества и развития научно-исследовательской инфраструктуры. Основные приоритеты Декады - контроль за состоянием океана, сильно изменяющимся в настоящее время вследствие климатических вариаций и интенсивной антропогенной нагрузки, предотвращение загрязнения океана, охрана морских экосистем, развитие морских прогнозов, как краткосрочных, так и долгосрочных климатических, а также прогнозирование опасных явлений и защита от них, создание открытых информационных ресурсов и международный обмен данными и технологиями, а на этой основе рациональное использование ресурсов океана. Важными вехами Декады должны стать создание цифрового атласа океана и других информационных систем, включающих информацию о рельефе дна, характеристиках морской воды, течениях, морских экосистемах, а также развитие глобальных систем наблюдения за океаном с использованием современных автономных обсерваторий. 


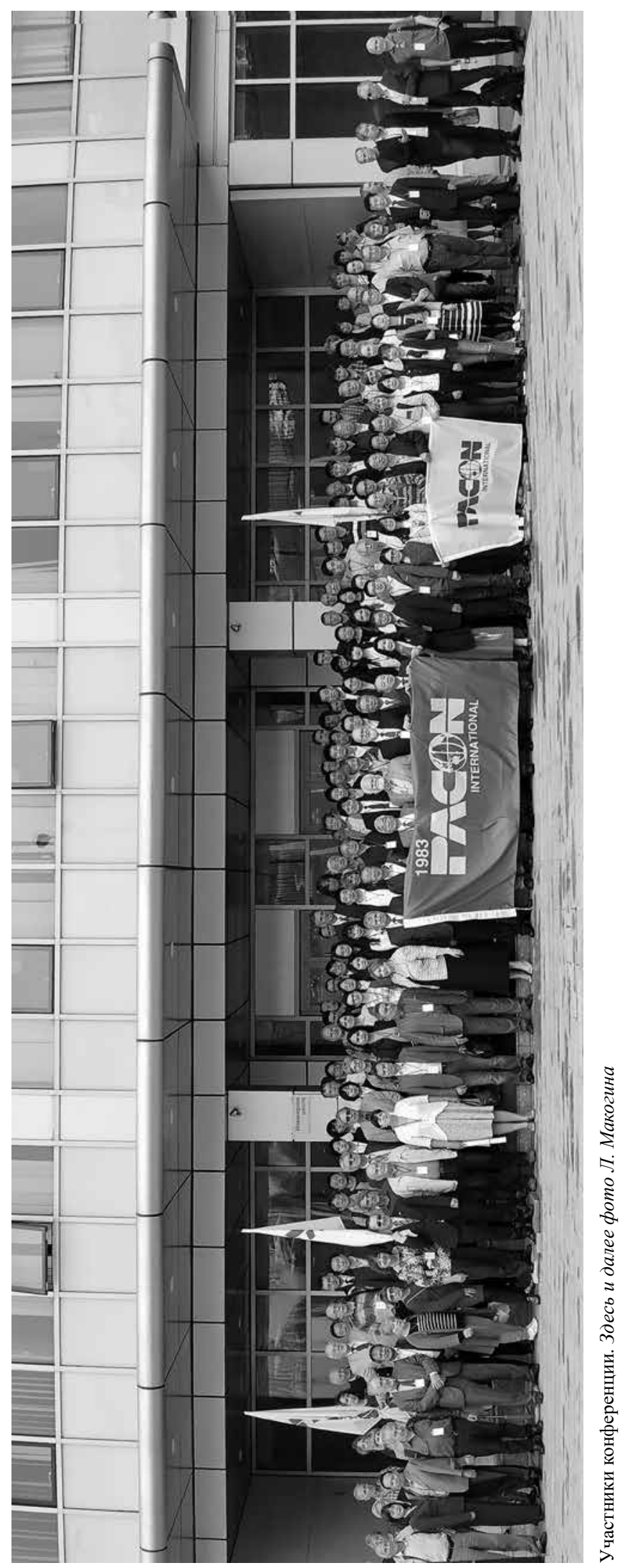


Тема 1 объединяла доклады по динамике океана и климату. Ю.Д. Чашечкин (Институт проблем механики имени А.Ю. Ишлинского РАН, Москва) представил пленарный приглашенный доклад, в котором вводились инварианты уравнений гидродинамики для разномасштабных структурных элементов циркуляции вод, в том числе синоптических вихрей и мезомасштабных волн и лигаментов (струй); были приведены примеры обсуждаемых структур в лабораторных экспериментах и природной среде. Климатическая система Земли испытывает колебания различных временных масштабов - от межгодовых до междесятилетних, отмечены тенденции потепления, между тем процессы, определяющие эти изменения, до сих пор изучены недостаточно. Были представлены доклады по междесятилетним колебаниям климата и сдвигу климатического режима на рубеже XX и XXI вв., а также секционный приглашенный доклад С.К. Коновалова (Морской гидрофизический институт, г. Севастополь) о долгосрочных изменениях кислородосодержания в Черном море. Доклады, представленные китайскими коллегами, были посвящены климатическому циклу Эль-Ниньо - южное колебание (ENSO). В частности, рассматривались модуляции ENSO при изменениях влагообмена между океаном и атмосферой, поток тепла, проникающий в толщу вод за счет цветения фитопланктона, процессы, происходящие в Индийском океане и в субтропиках южной Пацифики. Подчеркивался вклад в модуляцию ENSO мезомасштабных атмосферных процессов: тропических циклонов в западной части Тихого океана, волн неустойчивости в тропиках, ветрового режима в восточно-тропической части Тихого океана. Обсуждались проблемы гидродинамического моделирования и прогнозирования ENSO.
Значительное внимание было уделено процессам синоптического и мезомасштабов в океане и атмосфеpe. Секционный приглашенный доклад С.В. Пранца (ТОИ ДВО РАН) был посвящен кинематике морских вихрей в районе Камчатского желоба по результатам лагранжева анализа скорости течения по данным спутниковой альтиметрии. Обсуждалось влияние гидрологических условий северо-западной части Тихого океана на миграцию и скопления промысловых видов - сайры, сардины и макрели, короткопериодная изменчивость вертикальной структуры вод Японского моря в районе юго-восточного побережья Приморского края, гидродинамическое моделирование вихревой динамики в дальневосточных морях. В секционном приглашенном докладе Х. Чой (Республика Корея) показал, что образование тумана в прибрежных районах может быть связано с подходом холодного фронта внетропического циклона. Обсуждались экстремальные условия в океане: воздействию ветрового волнения в условиях сильного ветра на потоки тепла, влаги и импульса между океаном и атмосферой был посвящен пленарный приглашенный доклад А. Бабанина (Австралия). Изменения режима ветрового волнения в Чукотском море, происходящие вблизи кромки льда, обсуждались в секционном приглашенном докладе (Т. Васеда, Япония): на основе судовых наблюдений в ноябре установлено, что ветровые волны, хотя и существенно ослабляются, продолжают распространяться подо льдом, а для корректного расчета характеристик волнения вблизи кромки льда необходимо знать ее точное положение.

В рамках темы 2 (Морская геология и геологические ресурсы океана) работала секция по газогидратам в Тихом океане, важность которых определяется

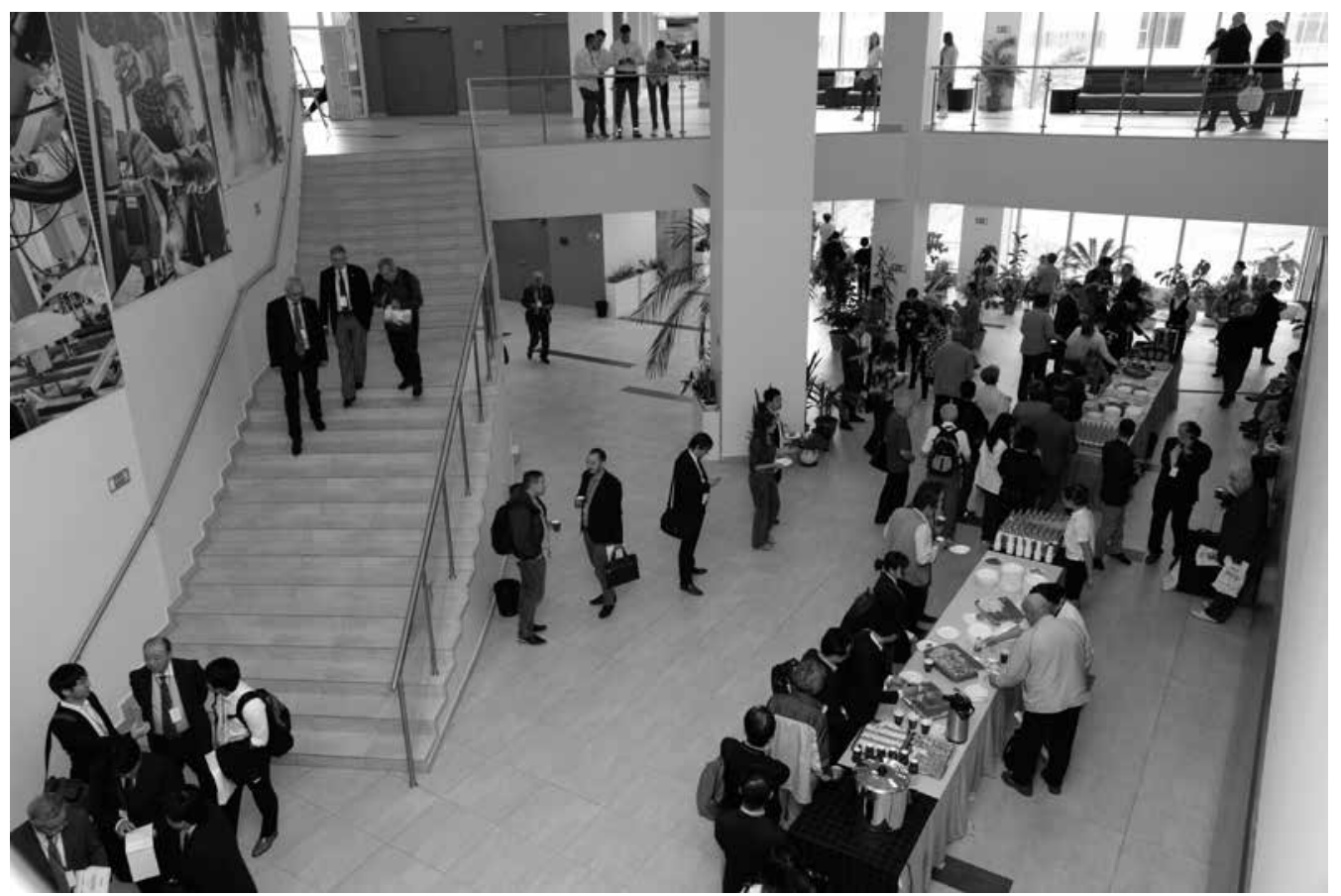

В перерыве 


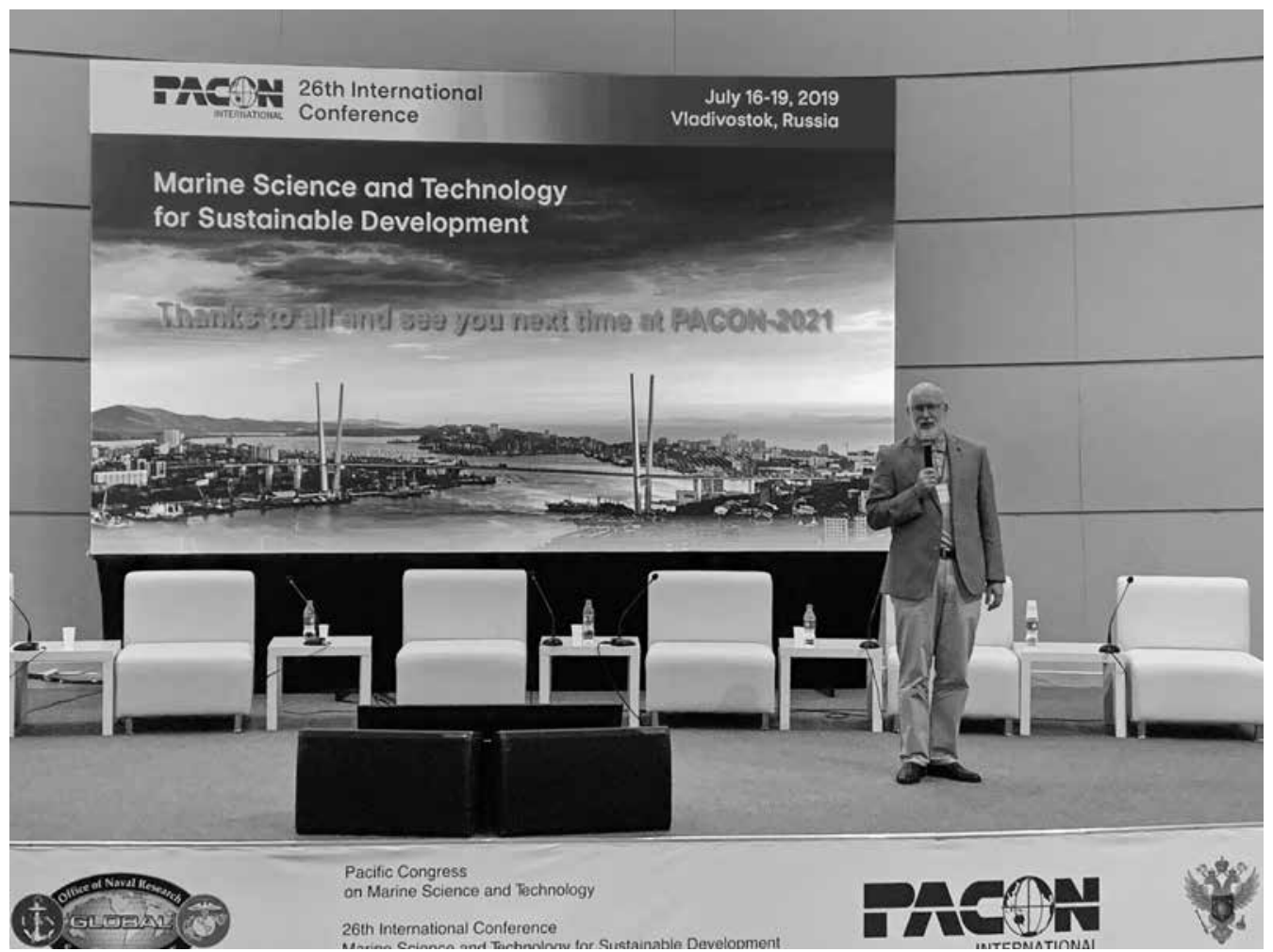

В.Б. Лобанов подводит итоги конференции

их взаимосвязью с месторождениями нефти и ролью в климатической системе как источника парниковых газов. Был представлен секционный приглашенный доклад по многолетним исследованиям газогидратов в Японском и Охотском морях (А.И. Обжиров, ТОИ ДВО РАН, г. Владивосток), обсуждался международный (Россия, Корея, Япония, Вьетнам) проект по исследованиям газогидратов в морях Восточной Азии (CoSGAS), были проанализированы потоки метана между поверхностью Японского моря и атмосферой. Работа особой секции была посвящена проблемам седиментологии и палеоокеанологии в Тихоокеанском регионе. Важность этой тематики определяется обостряющейся в настоящее время эрозией морских берегов, а также возможностью прогнозирования будущих климатических изменений на основе информации о колебаниях климата в прошлом, основанной на прокси-данных, полученных из донных морских осадков. Обсуждались также общие вопросы морской геологии, в частности геологические формации окраинной зоны в районе п-ова Камчатка, роль тектонических процессов в формировании дельты Красной реки (Вьетнам), вулканические и сейсмические процессы, а также российско-китайское сотрудничество в области исследования геологических ресурсов океана.

Тема 3 была посвящена проблемам морских экосистем и морских биологических ресурсов. В рамках этой темы было сделано два пленарных приглашенных доклада. А.В. Адрианов (Национальный научный центр морской биологии имени А.В. Жирмунского (ННЦМБ) ДВО РАН, г. Владивосток, Президиум РАН,
Москва) продемонстрировал яркие примеры биоразнообразия в глубинных и абиссальных водах северозападной части Тихого океана. Ю.И. Зуенко (ТИНРО, г. Владивосток) рассмотрел изменения экосистемы Охотского моря в условиях потепления климата в последние десятилетия, происходящие в направлении уменьшения продуктивности и увеличения эффективности. На секции по загрязнению морской среды значительное внимание привлек приглашенный доклад по радиоактивному загрязнению почв прибрежных районов северо-восточной части о-ва Хонсю после аварии на АЭС «Фукусима» в 2011 г. (С. Нагао, Япония). Обсуждались получающие в настоящее время все большую актуальность проблемы загрязнения морской среды пластиком и микропластиком, прибрежных вод Китая - нитратами и нитритами, гидробионтов - тяжелыми металлами и другими токсичными соединениями. Обсуждались также вопросы, связанные с реакцией морских экосистем на изменения свойств морской среды вследствие климатических изменений, гипоксии, ацидификации и нитрофикации морской воды.

Тему 4 можно коротко назвать «Океан и человек». Здесь обсуждались проблемы, являющиеся связующим звеном между фундаментальными научными и техническими задачами, с одной стороны, и повседневной социально-экономической деятельностью людей - с другой. Доклады охватывали широкий круг вопросов - от роли человеческого фактора при эксплуатации морского транспорта и технологических объектов, размещенных в морской среде, до 
таких, как влияние морской среды на здоровье человека, употребление водорослей в пищу, воздействие на человека загрязнений морской среды и очистка сточных вод.

Тема 5 была посвящена исследованиям и освоению ресурсов Арктики. На специальной секции по углеродному циклу в арктической прибрежной зоне был представлен приглашенный доклад И.П. Семилетова (ТОИ ДВО РАН, г. Владивосток), основанный на результатах многолетних исследований, в котором обсуждалась важная роль береговой абразии и потоков со дна в районах арктического шельфа в балансе парниковых газов (углекислого газа и метана) в этом регионе. В других докладах обсуждались колебания климата в масштабах от тысяч лет и более (по результатам анализа донных осадков), вынос взвесей с речным стоком на шельф морей восточной Арктики и межгодовая изменчивость этих потоков, методы измерения потоков метана на границах раздела вода - донные осадки, вода - воздух, особенности распространения звука в арктических водах и оценка параметров морской среды в Арктике с использованием акустических данных.

В рамках темы 6 обсуждались проблемы морского инжиниринга, строительства и эксплуатации портовых и прибрежных сооружений, в том числе для разведки и добычи углеводородных ресурсов, включая зоны с ледяным покровом разной степени тяжести, методы и средства защиты от цунамиопасности. Следует отметить широкое участие в работе секций этой темы сотрудников, аспирантов и студентов ДВФУ (г. Владивосток) и Университета Нихон (Япония)

Тема 7 была посвящена подводным аппаратам и роботам, а также акустическим исследованиям в Тихом океане. Доклады по подводным аппаратам и роботам включали как теоретические, так и экспериментальные результаты, были продемонстрированы

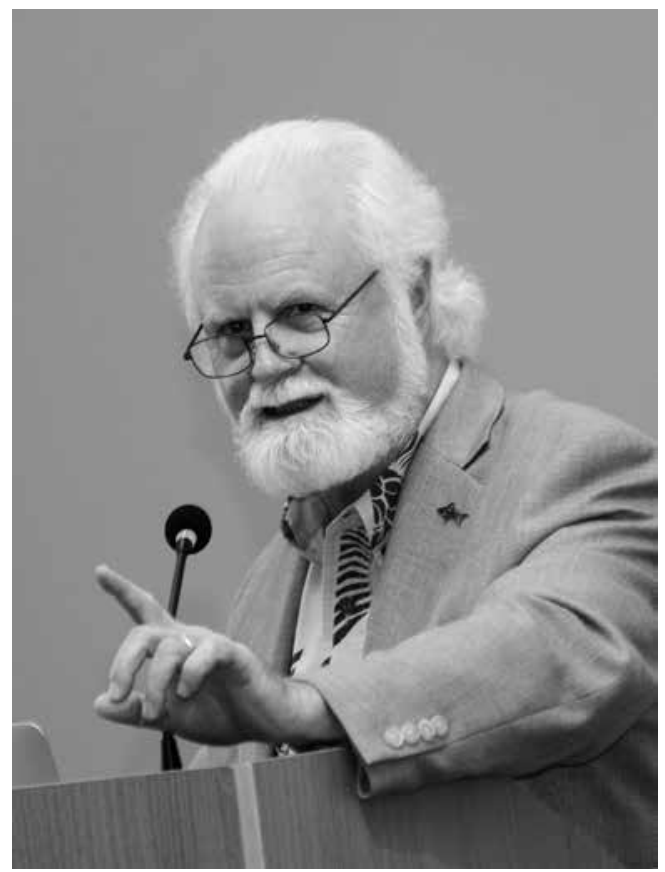

М. Кросби

весьма различные подходы, методы и технические решения для создания подводных роботов и управления ими. В работе секции принимали активное участие студенты ДВФУ. Что касается подводной акустики, здесь значительное место занимали приложения для исследования различных процессов в океане, чему были посвящены два пленарных приглашенных доклада. Дж. Боннель (США) рассказал об акустической идентификации усатых китов с помощью одного

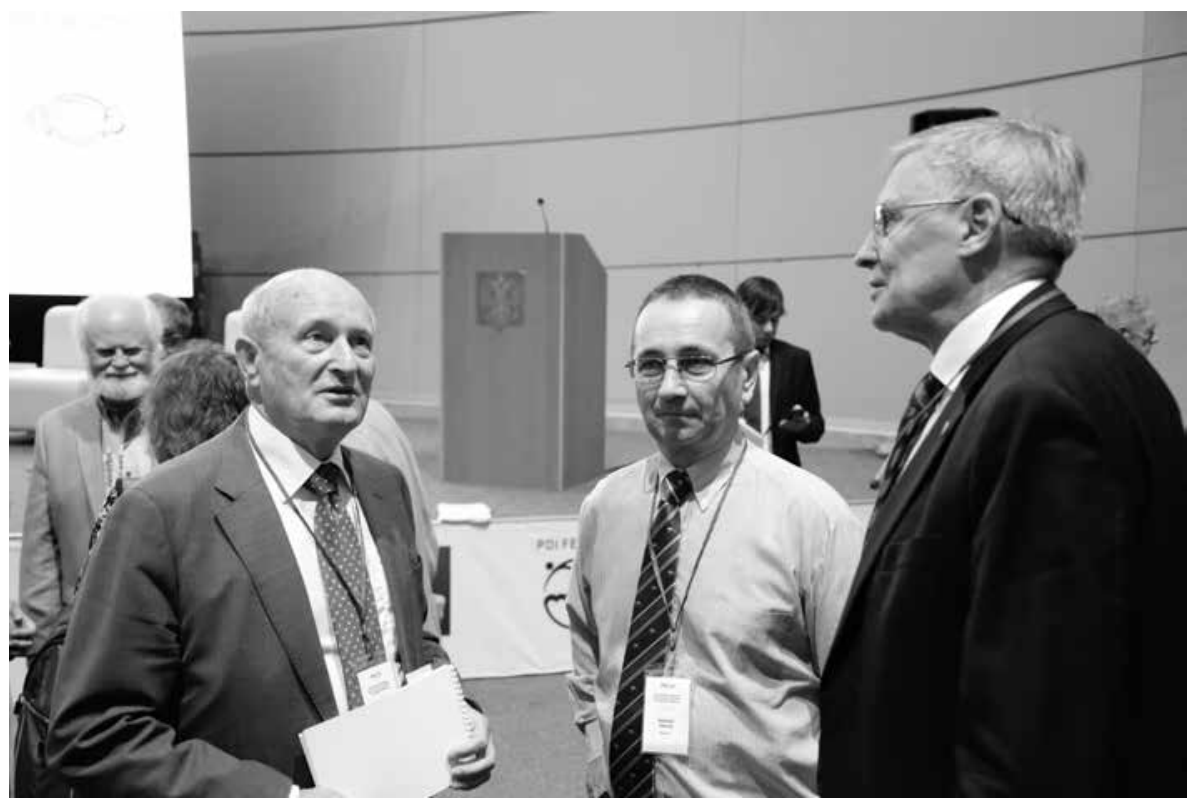

А.Т. Беккер, А.В. Бабанин, С.М. Шаповалов (слева направо) 


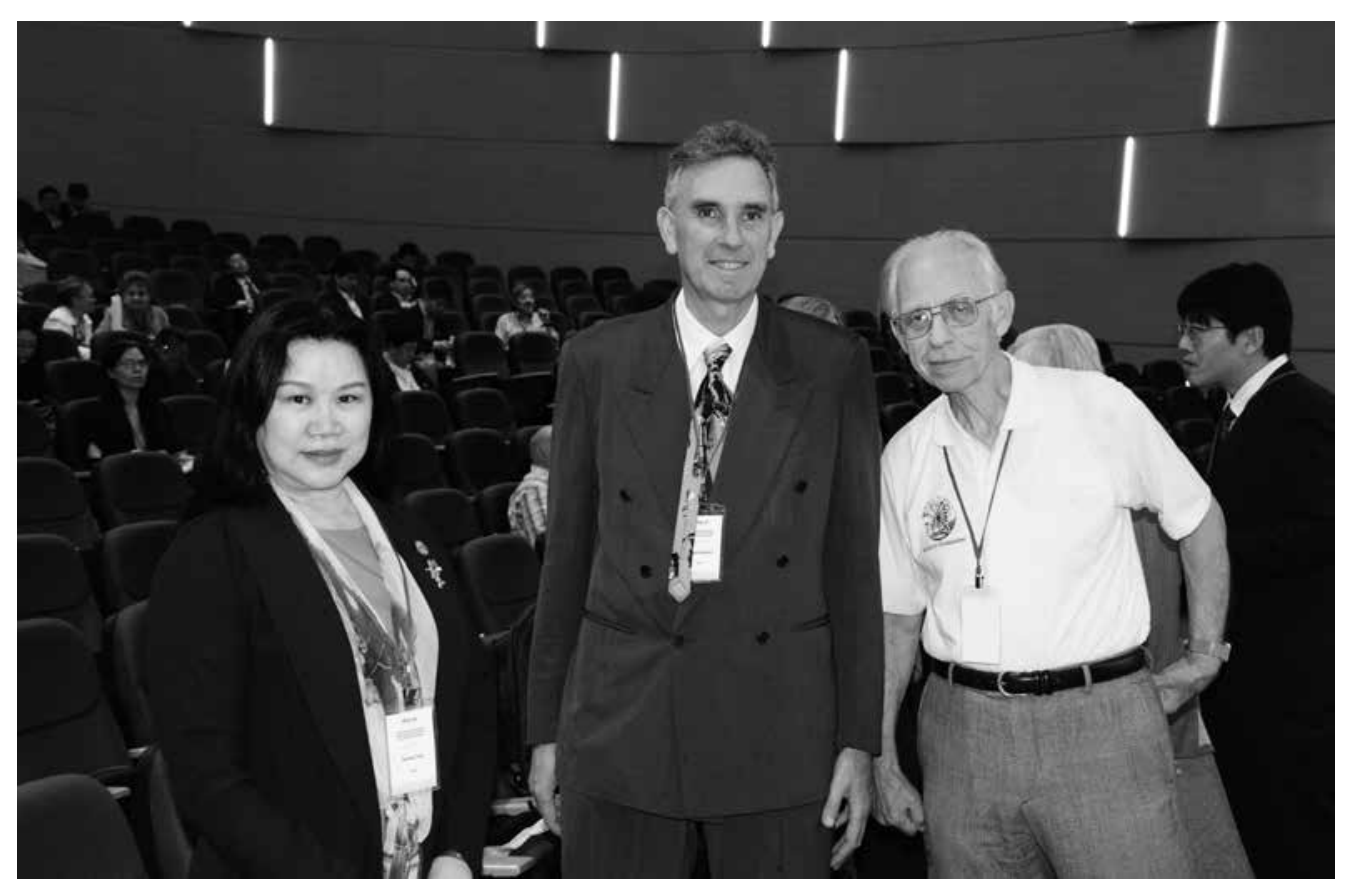

Д. Тан, С. Вигнуделли, Л.М. Митник (слева направо)

гидрофона, А.А. Луньков (Институт общей физики им. А.М. Прохорова РАН, Москва) - об изменениях скорости звука в мелководных районах при наличии метана в донных осадках и о методике определения концентраций метана по этим изменениям. Докладчики подчеркивали, что в рамках PACON облегчены контакты и междисциплинарная кооперация между гидроакустиками и специалистами из других отраслей океанологии, что должно способствовать все большему применению акустических методов для исследования океана.

Тема 8 - опасные и особо опасные морские явления. Секционный приглашенный доклад Б.Х. Лонга (Вьетнам) был посвящен последствиям прошедшего в районе побережья центральной части Вьетнама тайфуна «Дамри» в ноябре 2017 г. Обсуждались системы оповещения о цунамиопасности и изменения береговой линии и рельефа дна вблизи берега после цунами, системы прогнозирования штормовых нагонов (подъемов уровня воды у берега), защита природных водоемов от утечек радиоактивных материалов при эксплуатации АЭС, методы оценки возможных резонансных колебаний в мелководных морях и других водоемах и связанных с ними нагонов.

В рамках темы 9 рассматривались проблемы рыболовства, увеличения рыбозапасов в Тихом океане и развития аквакультуры. В докладах обсуждались история и инновации промышленного рыболовства, новые технологические решения для поиска промысловых скоплений и оценки их мощности, проблемы промышленного рыбоводства и выживания выпущенных в природную среду мальков, а также экосистемные подходы к промышленной аквакультуре, проблемы аквакультуры морских водорослей, трепангов и морских ежей, применение рециркуляционных систем аквакультуры, развитие промышленной аквакультуры на Дальнем Востоке России и воздействие потепления климата на гидробионтов и экономическую эффективность аквакультурных предприятий. Докладчики подчеркивали, что биоресурсы океана способны удовлетворить потребности в сбалансированном питании для возрастающего населения Земли, a PACON - организация, которая может продвигать эту тематику в деловую среду и сферу государственного и муниципального управления.

Тема 10 была посвящена методам и средствам измерения параметров морской среды. Здесь значительное место занимали вопросы применения данных дистанционного зондирования для исследования морской среды и пограничного слоя атмосферы, чему было посвящено два пленарных приглашенных доклада. С. Вигнуделли (Италия) рассказал о возможностях спутниковой альтиметрии для оценки изменений уровня моря в прибрежных районах, для чего необходимы специальные методы обработки принимаемого радарного сигнала и сопутствующих микроволновых данных, используемых для атмосферной коррекции. Л.М. Митник (ТОИ ДВО РАН, г. Владивосток) продемонстрировал возможности радара с синтетической апертурой, установленного на борту спутника ALOS-2, для регистрации динамических процессов и явлений в пограничном слое атмосферы над океаном: фронтальных разделов, вихрей и вихревых цепочек, линий шквалов, осадков, организованных мезомасштабных структур, таких как валиковые структуры, открытые и закрытые конвективные ячейки, подветренные волны. В других докладах сравнивались оценки параметров океана и атмосферы, полученные с отечественного спутника «Метеор-М» № 2 и спутника GCOM-W1, 


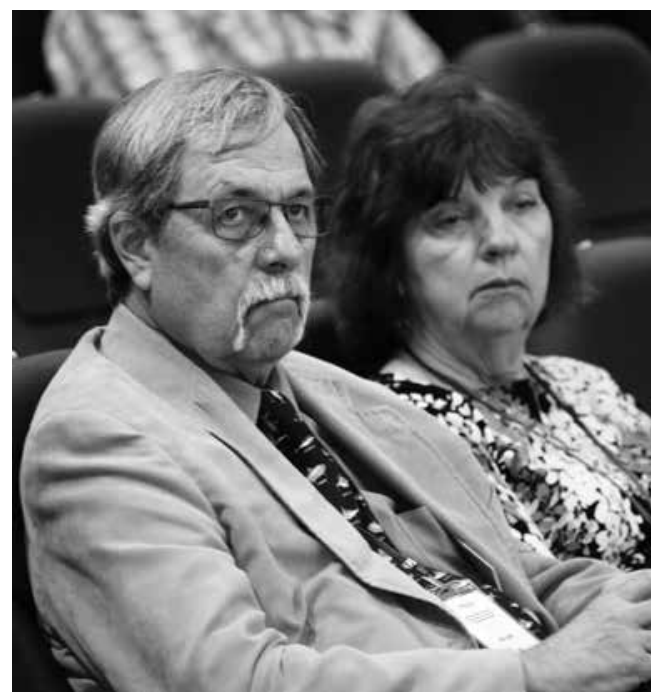

К. Лебер (слева), К. Мэйн

обсуждались восстановление приповерхностных морских течений по мультиспектральным данным со спутника Сентинел-2, алгоритмы для улучшения оценок векторов ветра по данным спутника CFOSA Т и оценок скорости сильных порывистых ветров по данным скаттерометра высокого разрешения в коротковолновом К-диапазоне, разделение вкладов фитопланктона и взвеси в видимое излучение моря в прибрежных водах повышенной мутности, изменения береговой линии бухты в зоне приливных течений. В докладах подчеркивалось, что спутниковая информация - весьма существенный источник данных об океане и атмосфере. Ее использование для научных исследований, изыскательских и проектных работ, мониторинга морской среды, в том числе опасных и особо опасных явлений, прогноза погоды, должно всемерно увеличиваться и поощряться. Соответствующие агентства должны обеспечивать для специалистов свободный доступ к данным и продуктам, полученным на их основе, а также к системам, интегрирующим их с другими источниками информации. Природа не знает границ, а спутниковые измерения проводятся вне юридических и политических барьеров, что делает их ценным средством международного сотрудничества.

Большое внимание было уделено системам мониторинга прибрежной зоны. А.Г. Зацепин (ИО РАН, Москва) представил пленарный приглашенный доклад о системе комплексного мониторинга в северовосточной части Черного моря (район г. Геленжик). Секционный приглашенный доклад П.А. Салюка (ТОИ ДВО РАН, г. Владивосток) был посвящен разработке концепции и реализации многоуровневого мониторинга морской среды зал. Петра Великого, Японское море, с использованием спутниковых данных, попутных малых судов, береговых и подводных пунктов видеонаблюдения, стационарных и дрейфующих буев и т.д. Обсуждалось новое направление, называемое гражданской наукой, в котором делается акцент на использование простых и недорогих средств измерений, например современных смартфонов, и компонентной базы для создания дешевых датчиков, а также на привлечение широкой общественности, в том числе студентов и старших школьников, к сбору данных о прибрежной морской среде. Были представлены результаты анализа колебаний уровня моря и ветрового волнения в зал. Петра Великого по данным системы видеорегистрации (в реальном времени). Обсуждались проблемы разработки баз океанологических данных, оценки параметров ветрового волнения при прохождении тайфуна «Конгри» над Японским морем (по спутниковым данным) и в прибрежной зоне моря (по данным прибрежных сейсмостанций), характеристики внутренних волн в шельфовой зоне Японского моря (по гидроакустическим данным) и изменение их

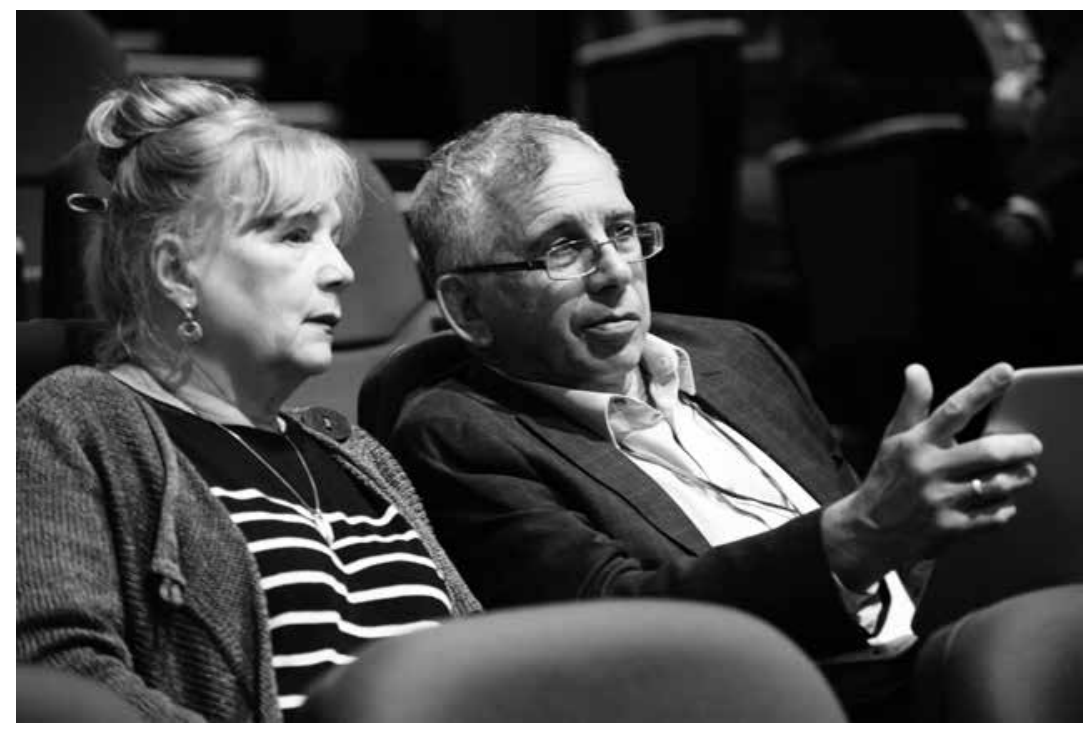

Л.Н. Василевская, И.П. Семилетов 


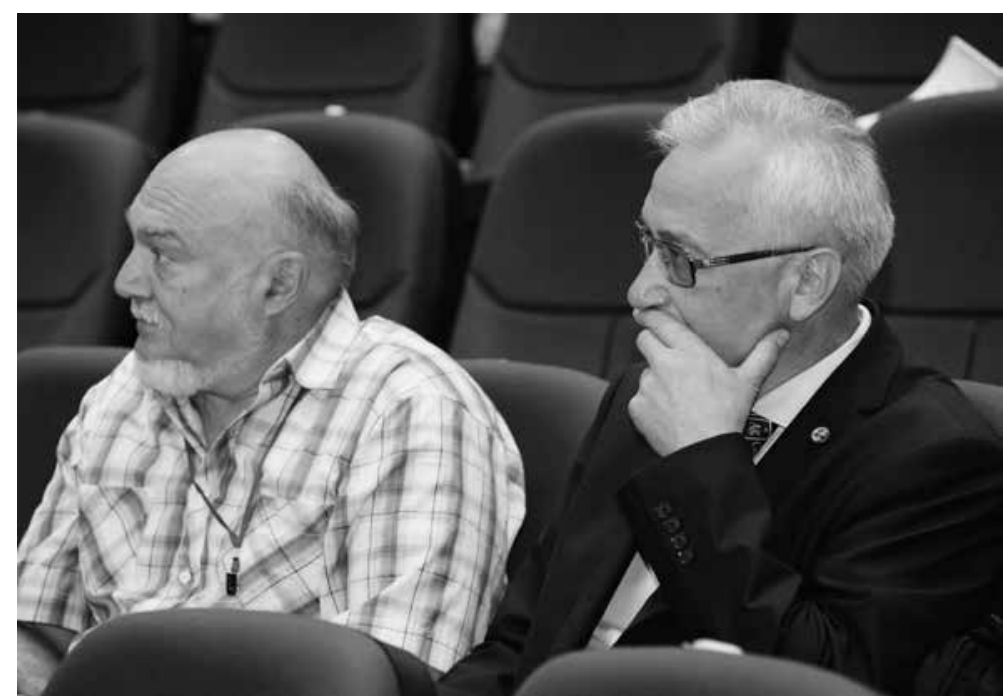

А.Г. Зацепин (слева), С.К. Коновалов

характера при переходе от глубокого моря к шельфу, а также связанные с этими процессами потоки энергии и придонных взвесей. Ряд докладов был посвящен измерению скорости течений, в том числе приливных (в Охотском море), с помощью дрифтеров, оценке океанологических параметров по данным стационарных буев в глубинных слоях Японского моря, инновационным системам для экспресс-анализа примесей в морской воде в экспедиционных условиях.

Тема 11 была посвящена экономическим, юридическим и общественно-политическим проблемам освоения океана. Важность этих вопросов для PACON подчеркивает тот факт, что на конференции были представлены 3 пленарных приглашенных доклада по данной теме. В докладе основателя РАCON M. Кросби (США) обсуждалась развиваемая в Японии концепция Sato-Umi, подразумевающая, с одной стороны, использование морских ресурсов прибрежной зоны, с другой - охрану и развитие этих ресурсов за счет грамотного управления хозяйственной деятельностью. 3. Арифин (Индонезия) представил доклад о развитии и вызовах национальных исследований океана и мерах, предпринимаемых на государственном и местном уровнях для бережного использования морских ресурсов. Дж. Дива-Акаллар (Филиппины) рассказала о роли международных организаций в реализации программы «Платформа устойчивого развития знаний о Мировом океане», выполняемой в преддверии Декады ООН.

Обсуждались проблемы экотуризма, экологических проектов и образования в сфере морских наук, рассматривались вопросы морской политики и комплексного управления морскими акваториями.

В ходе дискуссии на заключительном заседании неоднократно звучало, что конференция PACON-2019 стала успешным и впечатляющим событием. Подчеркивалось, что тенденция к налаживанию взаимопонимания и взаимодействия между учеными, инженерами, образовательными учреждениями, деловыми кругами и органами управления на местном и госу- дарственном уровнях является одним из приоритетов PACON: на каждой конференции помимо секций, где представляются научные доклады, проходят дополнительные мероприятия. В связи с этим было предложено на следующей конференции организовать специальные семинары и совещания для представителей местных администраций и деловых кругов, учителей средних школ, преподавателей и студентов университетов, чтобы обсудить на родном языке в доступной форме научные и технические достижения в сфере мореведения и пути их практического применения в местных условиях. Подчеркивалась важность вовлечения студентов и молодых специалистов в научные дискуссии и передачи молодежи знаний и опыта от старшего поколения ученых.

По итогам конференции принята следующая резолюция.

PACON будет продвигать и поддерживать международное сотрудничество в сфере морских наук в целях охраны морской среды, рационального использования морских ресурсов, поддержания биоразнообразия морской среды в рамках программы $\mathrm{OOH}$ «Платформа устойчивого развития знаний о Мировом океане» и в поддержку Декады исследования океана для устойчивого развития (2021-2030 гг.).

PACON будет добиваться осуществления следующих целей:

1. «Чистая» морская среда (с выявлением и устранением источников загрязнений).

2. Устойчивое и продуктивное использование морских биоресурсов для обеспечения человечества продуктами питания.

3. «Здоровая и самовосстанавливающаяся» морская среда (с картированием и охраной морских экосистем).

4. Безопасная морская среда (с защитой человечества от опасных гидрометеорологических явлений).

5. «Прозрачная» система знаний о морской среде (со свободным доступом к данным, информации и технологиям). 
6. Прогнозируемая морская среда (с пониманием ее нынешнего и будущего состояния).

Программа конференции РACON-2019, сборник тезисов, фотогалерея и презентации пленарных докладов доступны на сайте https://www.pacon-conference. org/.

Благодарим Российский фонд фундаментальных исследований, Министерство науки и высшего образования, Северотихоокеанскую морскую научную организацию (PICES) и Всемирное управление по морским исследованиям (ONRGlobal) за оказанную финансовую поддержку.

* O.О. ТРУСЕНКОВА - кандидат технических наук, ведущчий научный сотрудник (Тихоокеанский океанологический институт им. В.И. Ильичёва ДВО РАН, Владивосток),

В.Б. ЛОБАНОВ - кандидат географических наук, директор (Тихоокеанский океанологический институт им. В.И. Ильичёва ДВО РАН, Владивосток), Президент РАCON. *E-mail:trolia@poi.dvo.ru 